\title{
US-VERSUS-THEM POLARIZATION IN THE US PRESIDENTIAL DEBATES OF 2000
}

\author{
Denis S. Mukhortov, Elizaveta A. Zhovner \\ Lomonosov Moscow State University, Moscow, Russia \\ Leninskiye Gory 1, Moscow, Russia, 119991
}

\begin{abstract}
Political discourse as a specific sign system in which the meaning depends on the speaker's intention tends to portray participants in terms of "us" versus "them", which makes "us-versus-them" polarization one of the main distinguishing features of political discourse. The onset of the 21st century is a turning point in the history of geopolitics, which requires politicians to be more creative in search of vote-winning means. The pragmasemantic approach allows to study presidential debates between G.W. Bush and Al Gore from the standpoint of semantics which studies meaning and which has been recently affected by pragmatics that deals with non-linguistic aspects of meaning such as the context of a situation and the speaker's intention. The presidential debates of 2000 are a vivid illustration of how two opposing politicians strive to share the same objective though different language means. The contentanalysis program LIWC (Linguistic Inquiry and Word Count) was used in order to verify the results of research. The analysis of Pronouns, Positive/Negative Emotions, and Tense Focus through LIWC makes a contribution to political discourse studies. This article illustrate how various language means such as use of pronouns "we" and "they", specific vocabulary and slogans, when grouped together, can appear to be an efficient research tactic.
\end{abstract}

Key words: pragmalinguistics, stylistic idiosyncrasies, a politician's stylistic behavior, pragmasemantic analysis, status-bound type of language identity

\section{INTRODUCTION}

The compartmentalization of reality into "us" and "them" has socio-cultural roots. It means that people are guided not only by universal values but also by collective interests. These interests can be different for different groups. As a result, people unite in groups, and these groups oppose each other and are regarded as "us" and "them" groups [1. P. 45]. These divisions exist in different spheres of our lives: in psychology, literature, politics, and others.

Some scholars claim that people tend to think in an ambivalent way because of the binary structure of their nervous system [2. P. 82]. This is to suggest that people tend to have double standards and binary oppositions in their consciousness. Hence, people unconsciously cordon reality into the categories of "good", which is linked with "wanting", and "bad" _ " "not wanting" [3. P. 51]. This division creates two polar conceptual systems in people's minds, based on positive and negative assessments.

The opposition between "us" and "them" is a cultural constant alongside with such conceptual oppositions as "male/female", "old/young", "life/death", "light/darkness" [4. P. 150]. As the opposition "good/bad" is the basis for morality, the opposition "us/them" is the basis for opposition in politics, and other oppositions are subservient to it. 
Another important factor is that the "us-versus-them" polarization is closely connected with the notion "agonism", which derives from the Greek word "agon", meaning "contest" [5. P. 1]. The concept of agonism can be applicable to micro-contexts (such as a classroom or a workplace) and to macro-contexts such as a political arena: both include attempts "to de-centre other's identity" [6. P. 798]. Hence, in political context agonism means confrontation between two contenders.

According to Mouffe, agonism is "a we/they relation where the conflicting parties, although acknowledging that there is no rational solution to their conflict, nevertheless recognize the legitimacy of their opponents" [7. P. 20]. Political communication includes three participants: the speaker ("we"), the audience whose support is sought by the speaker ("us"), and the opponent who aims to discredit the speaker ("them") [8. P. 209]. Therefore, the "us-versus-them" polarization, which is used "to present politicians in a positive way and to portray their political opponents negatively", is of special interest for many scholars [9. P. 583].

The article provides insights into essential works on political discourse (Sheigal, van Dijk, Wodak), political communication (Mikhalyova, Parshina), and selected works on how parts of speech work in political discourse and political communication (Pakholkova, Bramley, Pennebaker, Tausczik). For our research, we used a content-analysis program $L I W C$ - Linguistic Inquiry and Word Count. The program analyzes each loaded text file, word-by-word, and then compares each word of a text file with a dictionary file. It helps "to detect meaning in a wide variety of experimental settings, including attentional focus, emotionality, social relationships, thinking styles, and individual differences" [10. P. 24]. The research examines the transcripts of the talks by George W. Bush and Al Gore during the US Presidential Debates of 2000.

The paper asserts that "us-versus-them" polarization is viewed as a special instrument that reflects the manipulative and confrontational nature of political discourse. It helps to analyze politicians' communicative intentions in terms of dividing the electorate into two opposing groups: "us" and "them".

Political discourse includes what was said as well as who said that, where, when and how [11. P. 52]. "Us-versus-them" polarization forms the basis for political communication. The study of the means of its expression helps us see how politicians impact voters during presidential campaigns. The presidential debates of 2000 still remain meaningful for researchers as the outcome of the election led to the shift of ideology and change of interests, and this still affects the modern politics.

\section{US-VERSUS-THEM POLARIZATION}

Political communication can be built on the explanation of political position (orientation), search for supporters (integration) and struggle with an opponent (confrontation). This triad corresponds to "us-versus-them" polarization, therefore, orientation means identification of who belongs to the "us-group" and who belongs to the "them-group"; integration means the merging into the "us-group", and confrontation means the struggle against the "them-group" [4. P. 149]. By establishing "us-versusthem" separation, politicians seek to reduce "the complexity of actions and events to two distinct groups, one of which (us) is deemed to be good, the other (them) bad" [12. P. 515]. 
"Us-versus-them" division can be manifested "through a macro-strategy of positive "self"-image and negative image of the "other" [13. P. 5]. According to Wirth-Koliba, "us-versus-them" polarization is based on ideological oppositions: "“we' are trustworthy, credible, and the good ones, whereas 'they' are deceptive, unreliable, and the bad ones" [14. P. 29]. "Us-versus-them" opposition is a communicative category which determines politicians' social position and serves as a most widespread instrument in political struggle. As collective entities, "us" and "them" groups represent how various social actors are portrayed in political discourse [15. P. 56]. T. van Dijk defines "us-versusthem" as "a polarized structure controlling power abuse, domination, competition and cooperation among groups" [16. P. 69].

Us-versus-them polarization can be represented at different levels:

— at the morphological level: by means of personal and possessive pronouns;

- at the lexical level: with the help of targeted salutations and pragmemes special lexemes that contain pragmatic components;

- at the syntactic level by the placing of an agent in a sentence;

- by metaphors as a means of constructing reality;

— by explicit and implicit information in a speech act [17. P. 78].

In our research, we partly use this level division and analyze pronouns, word choice, and slogans as most telling means of "us-versus-them" polarization.

\section{Pronouns}

Pronouns play a leading role in creating "us" and "them" groups. They not only express person, number and gender as traditional grammarians say, they also should be studied in the context of interaction. Many languages have deictics as the speaker needs "to identify the participants in the discourse" [18. P. 60]. English pronouns are deictic as their semantic meaning is fixed but their denotative meaning varies and requires additional contextual information [19. P. 185].

We can refer both to "we" meaning "self + one other" and "we" meaning "self + humanity". Usually "we" is used to speak about "a group membership or a collective identity" [20. P. 9]. "We" and its derivatives us and our express collective involvement and have an affiliative and uniting sense.

Personal deixis of the pronoun "we" in presidential discourse can have two meanings: 1) we - "myself + people of my country"; 2) we - "myself + my administration, my party, my or my party's (my country's) values” [21. P. 121]. According to Pennebaker, "the premature use of we-words, much like the language of a politician, is often perceived as disingenuous and manipulative", however, it can serve as a rhetoric device [22. P. 146].

We can distinguish between two functions of the pronoun "we": expressing institutional identity and involving voters in the issue in question.

\section{Expressing institutional identity}

(1) BUSH: We need to explore our resources and we need to develop our reservoirs of domestic production. We also need to have a hemispheric energy policy where Canada, Mexico and the United States come together. 
(2) BUSH: So, in my state we toughened up the juvenile justice laws. We added beds. We're tough. We believe in tough love. We've got laws.

(3) GORE: We need to call upon Syria to release the three Israeli soldiers who have been captured. We need to insist that Arafat send out instructions to halt some of the provocative acts of violence that have been going on.

These examples show that Bush suggests his plans about developing energy production and toughening up laws on behalf of the government and administration in Texas, which makes his speech sound more significant for the voters. "We" does not imply only Bush but all government officials as well.

Gore speaks as a representative of the government and suggests measures for solving the Israeli-Palestinian conflict. The use of "we" gives the voters the feeling that people should not worry about the conflict because serious measures will be taken by the government.

\section{Involving voters in the issue in question}

(4) BUSH: So, I don't think they ought to look at us in any way other than what we are. We're a freedom-loving nation and if we're an arrogant nation they'll view us that way, but if we're a humble nation they'll respect us.

(5) GORE: We're America, and we believe in our future and we know we have the ability to shape our future. And we can renew and rekindle the American spirit and make our future what our founders dreamed it could be.

"We" increases connections between Bush and the voters; they are elemental in the speech. He talks about the whole nation highlighting its most important qualities - love for freedom and humility.

Gore talks about the country making all the people come together, which makes them equal. It is important for Gore to highlight that all the Americans build their future together with their leader.

The pronoun "we" includes the allies and potential supporters of politicians; the pronoun "they" refers to the concept of "enemy" - "someone who tries to destroy "us" [23. P. 17]. The pronoun "they" also contains collective meaning, but it is rather distant from collective "self" expressed by "we". Therefore, "they" is used for creating the image of "other" and it is going from the general to the specific.

\section{Creating the image of "other"}

(6) BUSH: I've said that eight years ago they campaigned on prescription drugs for seniors. And four years ago they campaigned on getting prescription drugs for seniors. And now they're campaigning on getting prescription drugs for seniors. It seems like they can't get it done.

(7) BUSH: We spent a lot of money to make sure people get health care in the State of Texas, and we're doing a better job than they are at the national level for reducing uninsured.

The first example shows that "they" creates a negative image of Bush's opponent and his party. Blaming his opponents for their failure to launch an effective campaign, for their words that are not matched by deeds Bush acts as an accuser and at the same time as a defender of the citizenry. 
The second example shows a distinct contrast between 'us' and 'them' which corresponds to the government at the federal and local levels, and "they" is used to create a negative image of the former.

\section{Going from general to specific}

(8) BUSH: The Strunk family in Allentown, Pennsylvania, I campaigned with them the other day. They make $\$ 51,000$ combined income, they pay about $\$ 3,500$ in taxes. Under my plan, they get $\$ 1,800$ of tax relief. Under Vice President Gore's plan, they get $\$ 145$ of tax relief.

(9) GORE: Listen, for 24 years I have never been afraid to take on the big drug companies. They do some great things. They discover great new cures and that's great. We want them to continue that. But they are now spending more money on advertising and promotion.

Going from general to specific is a good example of how the speaker convinces his voters that he thoroughly understands the situation. Speaking about tax cuts, Bush gives general information about his plan and then gives an example of one family in Pennsylvania. Gore, in his turn, favours reducing prices of drugs, which helps him sound more convincing.

Both Bush and Gore understand the importance of creating a sense of unity. Both of them want to show they know the situation completely, and this makes them closer to the voters. They speak on behalf of the whole country and make the voters part of their speech. However, at the same time, Bush seeks to create a negative image of his opponent.

\section{Word choice}

Equally important is use of vocabulary. It allows us to see a "pragmasemantic value" of the words as they serve to better understand linguistic profiles of the candidates, including their beliefs and intentions [24. P. 152]. When we speak about the choice of words, we naturally come to the term 'concept'. According to Siomkin, concept is a mental representation that determines how things are connected with each other and classifies objects due to their similarity [25. P. 162]. Concepts create a system of opinions and reflect cognitive and learning experiences of native speakers.

As concepts classify different phenomena they can create stereotypes. Stereotyping is a kind of manipulation as stereotypes are defined as a set of opinions and expectations based on the analysis of how people think and act [25. P. 162]. According to van Dijk, "the lexical expression of mental models in the discourse of powerful speakers may influence not only knowledge but also opinions in the mental models of recipients" [26. P. 472]. These models can lead to "polarization at all levels of discourse, emphasizing the Good properties of Us and Bad properties of Them" though specific lexicon and images [27. P. 35].

\section{Hawk and Dove Vocabulary}

The analysis of vocabulary reveals the politicians' attitudes regarding foreign policy, which makes them sound either like a dove (someone who opposes the use of military pressure to resolve a conflict) or like a hawk (someone who is eager to enter into war).

(10) BUSH: I believe the role of the military is to fight and win war and therefore prevent war from happening in the first place. 
(11) BUSH: We have an opportunity, really, if you think about it, if we're smart and have got a strategic vision and a leader who understands strategic planning, to make sure that we change the terms of the battlefield of the future.

(12) BUSH: But I think it ought to be one of our priorities to work with our European friends to convince them to put troops on the ground.

(13) GORE: The first priority has to be on ending the violence, dampening down the tensions that have arisen there.

(14) GORE: We need to insist that Arafat send out instructions to halt some of the provocative acts of violence that have been going on.

(15) GORE: I certainly don't disagree that we ought to get our troops home from places like the Balkans as soon as we can, as soon as the mission is complete.

These instances show that Gore sounds like a pacifist, his position is to keep peace and stop the violence. Bush, on the contrary, sounds like a hawk: he uses a very aggressive vocabulary and insists on interfering in other countries' conflicts.

\section{Interests vs. Values}

The choice of words in politicians' speeches also reflects the main concepts of their ideology. The concepts "interests" and "values" can be regarded to be the key concepts in Bush's and Gore's speeches. Let us take a look at these examples and see how these concepts reflect the candidates' ideologies.

(16) BUSH: Peace in the Middle East is in our nation's interests. Having a hemisphere that is free for trade and peaceful is in our nation's interests. Strong relations in Europe are in our nation's interest.

(17) BUSH: And I strongly believe we need to keep a presence in NATO, but I'm going to be judicious as to how to use the military. It needs to be in our vital interest, the mission needs to be clear, and the extra strategy obvious.

(18) BUSH: Your question was deployment. It must be in the national interests, must be in our vital interests whether we ever send troops.

(19) GORE: I see our greatest national strength coming from what we stand for in the world. I see it as a question of values. <...> But our real power comes, I think, from our values.

(20) GORE: We have to protect our capacity to push forward what America's all about. That means not only military strength and our values, it also means keeping our economy strong.

(21) GORE: I see a future when the world is at peace, with the United States of America promoting the values of democracy and human rights and freedom all around the world.

Bush focuses his attention on "interests" in his policy while Gore talks about the importance of "values". Bush concentrates on the unity of the community, repeating our national interests. The main issue included in the sphere of Bush's interests concerns foreign policy and military affairs.

Gore singles out "values" as the most significant point in his political views talking about democracy, human rights, and national strength. His policy represents his main American concept, the American dream, which is based on the Puritans' doctrine that proclaims that such values as liberty and equality exist for all. 


\section{Slogans}

A slogan is a memorable phrase to express a certain idea though repetitive use in a commercial, religious, political, or other context. According to Denton, "the brief slogan is an ideal means of calling attention to the key ideographs of movements such as equality, happiness, free speech, freedom, justice, rights, and peace [28. P. 155]. Short, catchy slogans remind the voters of the candidates' campaign message [29. P. 347].

A slogan is one of the genres in political discourse that represents the confrontational function. It expresses the main ideas or goals in short form. A slogan turns any political theory into a symbolic action [30. P. 72]. It can be perceived by the voters as a real action (or a set of actions) that will probably be implemented by a politician after his winning the election. One of the key goals of slogans is "to generate emotional responses and perform persuasive functions that could contribute to the mobilization of masses" [31. P. 2].

(22) BUSH: I want to make sure the seniors believe the promise made will be a promise kept, but I want younger workers to be able to manage some of their own money, some of their own payroll taxes in the private sector under certain guidelines, to get a better rate of return on their own money.

(23) BUSH: I think there was a good opportunity to bring Republicans and Democrats together to reform the Social Security system so seniors will never go without.

(24) BUSH: But there's a larger law. Love your neighbor like you would like to be loved yourself. And that's where our society must head if we're going to be a peaceful and prosperous society.

(25) GORE: Because I think that we need to give our democracy back to the American people.

(26) GORE: I think a woman's right to choose ought to be protected and defended.

(27) GORE: I see a future when the world is at peace, with the United States of America promoting the values of democracy and human rights and freedom all around the world.

Bush had three main slogans in his presidential campaign: he takes a strong position as a politician who keeps his promises, who thinks that two parties can work together for the prosperity of the USA, and who believes in the Golden Rule. These slogans serve as an instrument to help Bush build an image of a "uniter" who has strong beliefs and moral obligations.

Gore focuses on presenting himself as a true Democrat who spreads the ideas of liberty and equality and who fights for human rights - especially for women's rights. Hence, a slogan can also be a powerful instrument to express political views.

\section{LIWC}

The results of our research can be proved through computerized text analysis. In the 1990s, Pennebaker, Booth and Francis developed a computer program called LIWC - Linguistic Inquiry and Word Count. This program consists of "the processing component and the dictionaries" [10. P. 27]. It analyzes each loaded text file, word-byword, and then compares each word of a text file with a dictionary file. LIWC examines more than 80 categories and several language dimensions; for instance, the category of articles, the emotion word categories, etc. 
For our analysis of the Bush-Gore debates, we chose several the categories Pronouns, Positive/Negative Emotions, and Tense Focus (Past/Present/Future). According to Hart, all these categories are connected in the discourse space that includes three axes: socio-spatial ("us" versus "them"), temporal (past, present, future), and evaluative ("right" versus "wrong") [32. P. 164]. Vivid examples of social, temporal and epistemic relations are the phrases like "close friends/distant enemies", "near future/remote past", "close to the truth/far from the truth" [33. P. 58].

Table 1 shows that Bush concentrates on creating we-groups and establishing unity while Gore pays much more attention to creating the image of 'other'. When it comes to the discussion of foreign policy, both politicians use the pronoun 'we' more. The greatest use of the pronoun 'they' in the third debate round by Gore can be explained by the fact that Gore tends to blame the administration for wrong decisions in domestic policy.

According to Table 2, we can see that Bush tends to express more positive emotions while Gore has quite a negative mindset. The politician with a negative verbiage has a confrontational mindset [24. P. 153]. Bush's positive thinking, by contrast, lays the foundation for his goal to bring the voters together.

Table 1 / Таблица 1

Use of pronouns we and they /

Употребление местоимений we и they

\begin{tabular}{|l|c|c|}
\hline \multicolumn{1}{|c|}{ Pronouns (We) } & Bush & Gore \\
\hline Debate 1 & 2,18 & 2,07 \\
\hline Debate 2 & 3,41 & 2,78 \\
\hline Debate 3 & 2,23 & 2,14 \\
\hline Total Pronouns (They) & 7,82 & 6,99 \\
\hline \multicolumn{1}{|c|}{ Bush } & Gore \\
\hline Debate 1 & 0,99 & 0,98 \\
\hline Debate 2 & 0,85 & 0,81 \\
\hline Debate 3 & 0,72 & 1,10 \\
\hline Total & 2,56 & 2,89 \\
\hline
\end{tabular}

Table 2 / Таблица 2

Положительные и отрицательные эмоции /

Positive and negative emotions

\begin{tabular}{|l|c|c|}
\hline \multicolumn{1}{|c|}{ Positive Emotions } & Bush & Gore \\
\hline Debate 1 & 3,54 & 3,56 \\
\hline Debate 2 & 4,44 & 3,15 \\
\hline Debate 3 & 4,30 & 3,46 \\
\hline Total Negative Emotions & 12,28 & 10,17 \\
\hline & Bush & Gore \\
\hline Debate 1 & 1,07 & 1,60 \\
\hline Debate 2 & 1,10 & 1,78 \\
\hline Debate 3 & 1,03 & 1,35 \\
\hline Total & 3,20 & 4,73 \\
\hline
\end{tabular}


Употребление времен Past, Present, Future /

Focus Past, Present, Future

\begin{tabular}{|l|c|c|}
\hline Focus (Past) & Bush & Gore \\
\hline Debate 1 & 2,38 & 2,56 \\
\hline Debate 2 & 2,92 & 3,41 \\
\hline Debate 3 & 2,30 & 2,70 \\
\hline Total Focus (Present) & 7,60 & 8,76 \\
\hline \multicolumn{1}{|c|}{ Focus (Future) } & Bush & Gore \\
\hline Debate 1 & 14,36 & 11,85 \\
\hline Debate 2 & 15,71 & 12,80 \\
\hline Debate 3 & 16,78 & 12,73 \\
\hline Total & 46,85 & 37,38 \\
\hline & Bush & Gore \\
\hline Debate 1 & 2,35 & 1,77 \\
\hline Debate 2 & 1,38 & 1,02 \\
\hline Debate 3 & 1,78 & 1,86 \\
\hline Total & 5,51 & 4,65 \\
\hline
\end{tabular}

Positive and negative attitudes relate to time orientation and temporal focus of attention. According to Pennebaker and Tausczik, "negative ads focus on past actions of the opponent, and positive ads focus on the present and future acts of the candidate" [10. P. 31]. Table 3 shows that Bush uses more present and future tenses than Gore, hence he is more optimistic, while Gore, who criticizes a lot and uses past tenses, sounds more pessimistic.

The results of the LIWC-based analysis show that Bush has more initiative in the three debates whereas Gore demonstrates more restraint. Bush's positive thinking and future orientation yielded better results than Gore's negative mindset and focus on the past.

\section{CONCLUSION}

Overall, the outcome of the US presidential debates of 2000 is marked with a forward-looking optimism, predominance of interests over values and attempts to draw a portrait of united nation.

Bush's election campaign is characterized by his consistency, his desire to pursue a strict foreign policy, bring the nation together and act in the interest of the people. Gore stands up for such values as democracy, freedom and human rights. However, his negative vision of situations within the country makes him sound quite pessimistic; therefore, Gore's expectations to win are not fulfilled. And all is done through political language which shows the division of the reality into "us" and "them" through use of pronouns, concepts, slogans and, hence, reveals the struggle between the candidates.

Analyzing "us-versus-them" polarization shows that it is a balanced and measured rhetoric, the right choice of vocabulary, and his communicative strategy in general that secured Bush his victory and led to his winning the presidential election of 2000 . His victory laid the foundation for the modern political development of the world.

(C) Мухортов Д.С., Жовнер Е.А., 2018

Дата поступления: 12.12.2018

Дата приема в печать: 15.04.2019 


\section{REFERENCES}

1. Issers, I.O. (2008). Communicative strategies and tactics of Russian speech. Moscow: LKI. (In Russ.).

2. Antonova, A.V. (2010). Features of mass consciousness as a target of speech manipulation (on the material of the pre-election debate of the British politicians). Political Linguistics, 1 (31), 79-83. (in Russ.).

3. Wierzbicka, A. (1996). Semantics. Primes and Universals. N.Y.: OUP.

4. Sheigal, E.I. (2004). Semiotics of political discourse. Moscow: Gnozis. (in Russ.).

5. Sidorenko, A.V. (2013). Agonism as a linguistic phenomenon. URL: http://pglu.ru/upload/ iblock/18f/p30038.pdf (accessed: 18.04.2019). (in Russ.).

6. van Leeuwen, B. (2015). Absorbing the agony of agonism? The limits of cultural questioning and alternative variations of intercultural civility. Urban Studies, 52 (4), 793-808.

7. Mouffe, Ch. (2011). On the Political. Taylor \& Francis.

8. Malysheva, O.P. (2009). Communicative strategies and tactics in public speech (on the material of American and British political leaders). Izvestia: Herzen University Journal of Humanities and Science, 96, 206-209. (in Russ.).

9. Wodak, R. (2006). Language and Politics. In Encyclopedia of Language and Linguistics (2nd ed.). London: Palgrave Macmillan. pp. 577-594.

10. Pennebaker, J.W. \& Tausczik, Y.R. (2010). The Psychological Meaning of Words: LIWC and Computerized Text Analysis Methods. Journal of Language and Social Psychology, 29 (1), 24-54.

11. Zolyan, C.T. (2016). Semiotics and pragmasemantics of political discourse. Political linguistics, $3,47-77$.

12. Wodak, R. (2018). Language and Politics. In English Language: Description, Variation and Context (2nd ed.). London: Palgrave Macmillan.

13. Morgan, D. (2015). A Discourse of Legitimation: Beyond the 'war on terror' and towards Iran. URL: http://www.lboro.ac.uk/media/wwwlboroacuk/content/phir/documentsandpdfs/ topstudentessays/D\%20Morgan\%20-\%20Dissertation.pdf (accessed: 18.04.2019).

14. Wirth-Koliba, V. (2016). The Diverse and Dynamic World of 'Us' and 'Them' in Political Discourse. Critical Approaches to Discourse Analysis across Disciplines, 8 (1), 23 - 37.

15. Hampl, M. (2017). The Representation of Social Actors in Conflicting Discourse. Discourse and Ideology: Studies in Political Stylistics, 66 (4), 56-69.

16. van Dijk, T. (2015). Critical Discourse Studies: A Sociocognitive Approach. In Methods of critical discourse analysis (3rd ed.). London: Sage. pp. 63-85.

17. Mikhalyova, O.L. (2009). Political discourse: the specificity of manipulative influence. Moscow: Librokom. (In Russ.).

18. Palmer, F.R. (1976). Semantics (2nd ed.). Cambridge: Cambridge University Press.

19. Ulanova, S.B. (2002). Deixis as a feature of nomination. In Text and discourse: traditional and cognitive-functional aspects of research. Ryazan: RGPU. pp. 185-188. (in Russ.).

20. Bramley, N.R. (2001). Pronouns of Politics: the use of pronouns in the construction of 'self' and 'other' in political interviews. URL: https://igitalcollections.anu.edu.au/bitstream/1885/ 46225/6/02whole.pdf (accessed: 18.04.2019).

21. Pakholkova, L.M. (2012). Several features of pragmatics of personal deixis in institutional political discourse (on the material of inaugural speeches by leaders of the FRG, the RF, the USA). Vestnik of the Cherepovets State University, 3(2), 119-122. (in Russ.).

22. Pennebaker, J.W. (2011). The secret life of pronouns: What our words say about us. New York: Bloomsbury Press.

23. Gerő, M., Płucienniczak, P., Kluknavska, A., Navrátil, J. \& Kanellopoulos, K. (2017) Understanding Enemy Images in Central and Eastern European Politics. Towards an Interdisciplinary 
Approach. Intersections. East European Journal of Society and Politics, 3(3), 14-40. doi: 10.17356/ieejsp.v3i3.365.

24. Mukhortov, D.S. (2016). On several features of the lexical-semantical structure of the English pre-election discourse. Political linguistics, 9(1), 152-154. (in Russ.).

25. Syomkin, M.A. (2011). The role of concepts in forming of stereotypes of public opinion. Political linguistics, 2(36), 162-165. (in Russ.).

26. Van Dijk, T.A. (2015). Critical Discourse Analysis. In D. Tannen, H.E. Hamilton, \& D. Schiffrin (eds.) The Handbook of Discourse Analysis. New Delhi: John Wiley\& Sons, Inc. pp. 466485.

27. Van Dijk, T.A. (2018). Socio-cognitive discourse studies. In Flowderdew, J. and Richardson, J.E. (eds.) The Routledge Handbook of Critical Discourse Analysis. London-New York: Routledge. pp. $23-46$.

28. Denton Jr., R.E. (1980). The Rhetorical Function of Slogans: Classification and Characteristics. Communication Quarterly, 28 (2), 10-18.

29. Hodges, A. (2014). 'Yes, we can': The social life of a political slogan. In C. Hart, \& P. Cap (eds.) Contemporary critical discourse studies. Bloomsbury. pp. 347-364.

30. McConnell, F.D. (1971). Toward a Lexicon of Slogans, The Midwest Quarterly, 3(1), 69—90.

31. Lahlali, E.M. (2014). The Discourse of Egyptian Slogans: from 'Long Live Sir' to 'Down with the Dictator'. Arab Media and Society. URL: https://www.arabmediasociety.com/wpcontent/uploads/2017/12/20140926111357_Lahlali_Slogans_Final.pdf (accessed: 18.04.2019).

32. Hart, Ch. (2014). Discourse, grammar and ideology: Functional and cognitive perspectives. London: Bloomsbury.

33. Chilton, P. (2004). Analyzing political discourse: Theory and Practice. London: Routledge.

\title{
«СВОИ» И «ЧУЖИЕ» \\ В АМЕРИКАНСКИХ ПРЕДВЫБОРНЫХ ДЕБАТАХ 2000 ГОДА
}

\author{
Д.С. Мухортов, Е.А. Жовнер \\ Московский государственный университет имени М.В. Ломоносова \\ Ленинские горы, 1, г. Москва, Россия, 119991
}

Политический дискурс как знаковая система, в которой значение слова может зависеть от намерения говорящего, представляет участников дискурса с точки зрения категории «свои-чужие», одной из важнейших категорий политического дискурса. Начало XXI века является поворотным моментом в геополитике, политикам приходится изыскивать всё более искусные способы для привлечения избирателей на свою сторону. Прагмасемантический подход позволяет проанализировать дебатные выступления Дж. Буша-мл. и Альберта Гора с точки зрения как семантики, предметом изучения которой является значение слова, так и прагматики - дисциплины, которая в последнее время играет значительную роль в политическом дискурсе и занимается изучением ряда нелингвистических аспектов, таких как ситуативный контекст и намерение говорящего. На примере предвыборных дебатов 2000 года можно увидеть, как абсолютно разные политики стремятся достичь одной цели при помощи различных языковых средств. Данные, полученные с помощью компьютерной программы Linguistic Inquiry and Word Count (LIWC), подтверждают результаты исследования. Анализ категорий Pronouns, Positive/Negative Emotions и Tense Focus имеет особую ценность как 
для данного исследования, так и для изучения политического дискурса в целом. В конкретном случае репрезентация категории «свои-чужие» происходит за счет местоимений ше и they, выбора специфического вокабуляра и использования слоганов, анализ которых убедительно демонстрирует как одни приемы оказываются действеннее других и, как следствие, победа оказывается за тем выступающим, чьи дискурсивные тактики имеют больший манипулятивный потенциал.

Ключевые слова: прагмалингвистика, идиостиль, вербальное поведение политика, прагмасемантический анализ, социально-статусный тип языковой личности

\section{БИБЛИОГРАФИЧЕСКИЙ СПИСОК}

1. Иссерс О.С. Коммуникативные стратегии и тактики русской речи. М.: ЛКИ, 2008.

2. Антонова A.B. Свойства массового сознания как мишени речевой манипуляции (на примере текстов предвыборных выступлений британских политиков) // Политическая лингвистика. 2010. № 1 (31). С. $79-83$.

3. Wierzbicka A. (1996) Semantics. Primes and Universals. N.Y.: OUP, 1996.

4. Шейгал Е.И. Семиотика политического дискурса. М.: Гнозис, 2004.

5. Сидоренко A.B. Агональность как лингвистическое явление. 2013. URL: http://pglu.ru/ upload/iblock/18f/p30038.pdf (дата обращения: 18.04.2019).

6. van Leeuwen, B. Absorbing the agony of agonism? The limits of cultural questioning and alternative variations of intercultural civility // Urban Studies. 2015. No 52 (4). P. 793-808.

7. Mouffe Ch. On the Political. London: Taylor \& Francis, 2011.

8. Мальшева О.П. Коммуникативные стратегии и тактики в публичных выступлениях (на материале речей американских и британских политических лидеров) // Известия Российского государственного педагогического университета им. А.И. Герцена. 2009. № 96. C. 206-209.

9. Wodak R. Language and Politics. Encyclopedia of Language and Linguistics (2nd ed.). London: Palgrave Macmillan. P. 577-594.

10. Pennebaker J.W., Tausczik Y.R. The Psychological Meaning of Words: LIWC and Computerized Text Analysis Methods // Journal of Language and Social Psychology. 2010. No 29 (1). P. 24-54.

11. Золян С.T. Семиотика и прагмасемантика политического дискурса // Политическая наука. 2016. № 3. C. 47-77.

12. Wodak R. Language and Politics. English Language: Description, Variation and Context. 2nd ed. London: Palgrave Macmillan, 2018.

13. Morgan D. A Discourse of Legitimation: Beyond the 'war on terror' and towards Iran. 2016. URL: http://www.lboro.ac.uk/media/wwwlboroacuk/content/phir/documentsandpdfs/topstudentessays/ D\%20Morgan\%20-\%20Dissertation.pdf (дата обращения: 18.04.2019).

14. Wirth-Koliba V. The Diverse and Dynamic World of 'Us' and 'Them' in Political Discourse // Critical Approaches to Discourse Analysis across Disciplines. 2016. No 8 (1). P. 23 - 37.

15. Hampl M. The Representation of Social Actors in Conflicting Discourse// Discourse and Ideology: Studies in Political Stylistics. 2017. P. 56-69.

16. van Dijk, T. Critical Discourse Studies: A Sociocognitive Approach // Methods of critical discourse analysis. 2015. 3rd ed. London: Sage, 63-85.

17. Михалева О.Л. Политический дискурс: Специфика манипулятивного воздействия. М.: Либроком, 2009.

18. Palmer F.R. Semantics. 2nd ed. Cambridge: Cambridge University Press, 1976.

19. Уланова С.Б. Дейксис как свойство номинации // Текст и дискурс: традиционный и когнитивно-функциональный аспекты исследования: сборник научных трудов / под ред. Л.А. Манерко. РГПУ. Рязань, 2002. С. 185-188. 
20. Bramley N.R. Pronouns of Politics: the use of pronouns in the construction of 'self' and 'other' in political interviews. 2001. URL: https://digitalcollections.anu.edu.au/bitstream/1885/46225/ 6/02whole.pdf (дата обращения: 18.04.2019).

21. Пахолкова Л.М. Некоторые особенности прагматики персонального дейксиса в институциональном политическом дискурсе (на материале речей руководителей ФРГ, РФ и США при вступлении в должность) // Вестник Череповецкого государственного университета. 2012. № 3 (2). С. 119-122.

22. Pennebaker J.W. The secret life of pronouns: What our words say about us. New York: Bloomsbury Press, 2011.

23. Gerö M., Płucienniczak P., Kluknavska A., Navrátil J., Kanellopoulos K. Understanding Enemy Images in Central and Eastern European Politics. Towards an Interdisciplinary Approach // Intersections. East European Journal of Society and Politics. 2017. No 3 (3). P. 14-40. doi: 10.17356/ieejsp.v3i3.365.

24. Мухортов Д.С. О некоторых особенностях лексико-семантической структуры англоязычного предвыборного дискурса // Политическая лингвистика: проблематика, методология, аспекты исследования и перспективы развития научного направления. 2016. № 9 (1). C. $152-154$.

25. Семкин M.A. Роль концептов в формировании стереотипов общественного мнения // Политическая лингвистика. 2011. № 2 (36). С. 162-165.

26. Van Dijk T.A. Critical Discourse Analysis // The Handbook of Discourse Analysis / D. Tannen, H.E. Hamilton, \& D. Schiffrin (eds.). John Wiley\& Sons, Inc, 2015. pp. 466-485.

27. Van Dijk T.A. Socio-cognitive discourse studies // The Routledge Handbook of Critical Discourse Analysis / Flowderdew J and Richardson JE (eds.). London/New York: Routledge, 2018. P. 23-46.

28. Denton Jr. R.E. (1980) The Rhetorical Function of Slogans: Classification and Characteristics // Communication Quarterly. 1980. No 28 (2). P. 10-18.

29. Hodges A. 'Yes, we can': The social life of a political slogan // Contemporary critical discourse studies / C. Hart \& P. Cap (eds.). Bloomsbury, 2014. P. 347-364.

30. McConnell F.D. Toward a Lexicon of Slogans // The Midwest Quarterly. 1971. No 3(1). P. $69-90$.

31. Lahlali E.M. The Discourse of Egyptian Slogans: from 'Long Live Sir' to 'Down with the Dictator'. Arab Media and Society. 2014. URL: https://www.arabmediasociety.com/wp-content/ uploads/2017/12/20140926111357_Lahlali_Slogans_Final.pdf (дата обращения: 18.04.2019).

32. Hart Ch. Discourse, grammar and ideology: Functional and cognitive perspectives. London: Bloomsbury, 2014.

33. Chilton P. Analyzing political discourse: Theory and Practice. London: Routledge, 2004.

\section{For citation:}

Mukhortov, D.S. \& Zhovner, E.A. (2019). Us-versus-them polarization in the US presidential debates of 2000. RUDN Journal of Language Studies, Semiotics and Semantics, 10 (2), 499-512. doi: 10.22363/2313-2299-2019-10-2-499-512.

\section{Для цитирования:}

Мухортов Д.С., Жовнер Е.А. «Свои» и «чужие» в американских предвыборных дебатах 2000 года // Вестник Российского университета дружбы народов. Серия: Теория языка. Семиотика. Семантика. Т. 10. № 2. С. 499-512. doi: 10.22363/2313-2299-2019-10-2-499-512.

\section{Information about the authors:}

Denis S. Mukhortov, Ph.D. in Philology; Associate Professor, Department of English Linguistics, Lomonosov Moscow State University; e-mail: dennismoukhortov@mail.ru 
Elizaveta A. Zhovner, Department of English Linguistics, Faculty of Philology, Lomonosov Moscow State University; e-mail: lisayka@mail.ru

\section{Сведения об авторах:}

Мухортов Денис Сергеевич, кандидат филологических наук; доцент кафедры английского языкознания филологического факультета Московского государственного университета имени М.В. Ломоносова; научные интересы: герменевтическое исследование политического дискурса, семантический анализ гипертекста, лексико-семантические и синтаксические трансформации при переводе речей политика; e-mail: dennismoukhortov@mail.ru

Жовнер Елизавета Андреевна, магистрантка кафедры английского языкознания филологического факультета Московского государственного университета имени М.В. Ломоносова; научные uнтересы: герменевтическое исследование политического дискурса, семантический анализ гипертекста, анализ стратегий и тактик в предвыборном дискурсе; e-mail: lisayka@mail.ru 